\title{
Stability evaluation of $\left[{ }^{18} \mathrm{~F}\right] \mathrm{FDG}$ : literature study, stability studies from two different PET centres and future recommendations
}

\author{
Jes G. Holler', Børge Renmælmo ${ }^{2}$ and Richard Fjellakse ${ }^{3^{*}}$ (1)
}

\author{
*Correspondence: \\ Richard.fjellaksel@uit.no \\ ${ }^{3}$ Department of Health \\ and Care Sciences, UiT The \\ Arctic University of Norway, \\ Hansine Hansens veg 18, \\ 9019 Tromsø, Norway \\ Full list of author information \\ is available at the end of the \\ article
}

\begin{abstract}
Background: The need for a stability evaluation of $\left.{ }^{18} \mathrm{~F}\right] \mathrm{FDG}$ is evident. The main purpose of this study was to make recommendations for determining the shelf life based on the available stability literature and our own two-centre stability studies.

Results: We performed a non-systematic literature study to find the most relevant stability data for $\left[{ }^{18} \mathrm{~F}\right] \mathrm{FDG}$. The amount of radioactivity, radio-stabilizers, choice of synthesis, dilution, $\mathrm{pH}$, temperature, storage and the choice of stability tests and acceptance criteria were the most important factors to evaluate for the implementation of good manufacturing practice. Moreover, we discuss some limitations of the study, especially the choice of synthesis, photostability, the environment, temperature and storage. Based on these data, we designed our own two-centre stability studies. All the defined acceptance criteria were met.
\end{abstract}

Conclusions: We have made recommendations for future stability evaluations based on our findings. The most important findings were that the amount of the radiostabilizer ethanol should be $>0.1 \%$ ethanol for activities up to $4 \mathrm{GBq} / \mathrm{mL}$ and $>0.2 \%$ ethanol for activities up to $22.7 \mathrm{GBq} / \mathrm{mL}$ to keep $\left[{ }^{18} \mathrm{~F}\right] \mathrm{FDG}$ stable.

Keywords: $\left[{ }^{18} \mathrm{~F}\right] \mathrm{FDG}$, Stability, Quality control, Physiochemical aspects, Drug product development, Radiopharmaceutics, Pharmaceutics, Manufacturing process design

\section{Background}

There is a need for an $\left[{ }^{18} \mathrm{~F}\right] \mathrm{FDG}$ stability evaluation guide/checklist for radiopharmaceutical production sites. $\left[{ }^{18} \mathrm{~F}\right] \mathrm{FDG}$ has been adopted worldwide as the most widely used clinical positron emission tomography (PET) radiotracer since the first in human PET imaging in 1976 (Hess et al. 1976). There are several stability studies available. Hung (2002) compares different quality tests and demands in the United States Pharmacopeia) USP/European Pharmacopeia (Ph. Eur.)/The draft Chemistry, Manufacturing, and Controls (CMC) issued by the U.S. Food and Drug Administration (FDA) and Yu (2006) uses BP (British Pharmacopeia) as a quality reference standard (Hung 2002; Yu 2006). However, there is no review on updated stability evaluation based on available literature, recommendations and implementation for good manufacturing practice (GMP). Herein, we present a non-systematic literature study, stability studies of $\left[{ }^{18} \mathrm{~F}\right] \mathrm{FDG}$ from two

(c) The Author(s) 2022. Open Access This article is licensed under a Creative Commons Attribution 4.0 International License, which permits use, sharing, adaptation, distribution and reproduction in any medium or format, as long as you give appropriate credit to the original author(s) and the source, provide a link to the Creative Commons licence, and indicate if changes were made. The images or other third party material in this article are included in the article's Creative Commons licence, unless indicated otherwise in a credit line to the material. If material is not included in the article's Creative Commons licence and your intended use is not permitted by statutory regulation or exceeds the permitted use, you will need to obtain permission directly from the copyright holder. To view a copy of this licence, visit http:// creativecommons.org/licenses/by/4.0/. 
different PET centres and our recommendations for future $\left[{ }^{18} \mathrm{~F}\right] \mathrm{FDG}$ implementations for radiopharmaceutical production sites.

The stability of $\left[{ }^{18} \mathrm{~F}\right] \mathrm{FDG}$ is of high importance, especially considering the everincreasing number of patients diagnosed with the aid of $\left[{ }^{18} \mathrm{~F}\right] \mathrm{FDG}$, the number of PET centres and the availability of PET/CT or PET/MR scanners at hospitals. The stability of a drug is defined by its ability to maintain its properties during storage and use, as well as the rate at which the changes in these properties take place. The purpose of stability testing is thus to determine how a drug's quality is affected over time and under various conditions such as temperature, relative humidity, light, etc. A drug's shelf life can be defined as the period in which its stability and thus its efficacy and safety is found to be sufficient (ICH 2003a). The European Pharmacopoeia (Ph. Eur.) states that a preparation must be in accordance with the monograph throughout the shelf life of the product (Council of Europe 2019). PET radiopharmaceuticals often have a very short shelf life due to the short half-life of the PET radionuclides. Therefore, it may seem unnecessary to examine the stability of a product containing a radionuclide with a defined half-life and often a lifetime of less than a normal working day. However, several stability factors can affect the radiolabeled product during the lifetime, which is why it is important to examine stability.

The main routine production of $\left[{ }^{18} \mathrm{~F}\right] \mathrm{FDG}$ uses saline with a small percentage of ethanol, phosphate or citrate buffer in the synthesis. A two-centre study investigated the use of phosphate buffer in GE Healthcare's FASTlab synthesis cassettes module. It found that phosphate buffered reagent kits formed precipitation due to aluminium phosphate and thus did not recommend the use of phosphate buffered reagent kits even though another study found them to give the same radiochemical yield (Huang et al. 2016; Long et al. 2013). The main stability issue is radiation-related radiolysis of the active substance and solvents (Jószai et al. 2019; Buriova et al. 2005). These stability issues highlight the importance of this study.

\section{Quality measurements and $\left[{ }^{18} \mathrm{~F}\right] \mathrm{FDG}$ stability studies}

$\mathrm{Ph}$. Eur. states that a preparation must be in accordance with the monograph throughout the shelf life of the product. Furthermore, the authorities should assess stability based on experimental stability data (Council of Europe 2019).

The European Medicines Agency (EMA) follows the published guidelines for stability testing and retesting by the General International Council for Harmonization of Technical Requirements for Registration of Pharmaceuticals for Human Use's (ICH) (ICH 2003a; b). The guideline is divided into two sections, which deal with new "Drug substance" and "Drug product" respectively. Each section covers principles of stability testing and includes sub-sections on general considerations from the literature and experience, stress testing (active substance), photostability (product), sampling, primary/ secondary packaging, specification, test frequency, storage conditions, stability commitment, evaluation, and guidance/labelling for use. There is also an extended version of this guideline which describes stability testing of existing substances and related finished products, guidelines for stability testing, and stability testing of active substances and related finished products. This extension contains the same sections but applies to products that have already been approved with the same active substance. However, there are 
exceptions, including radiopharmaceuticals, which must be treated in accordance with the guideline in the main document. Furthermore, EMA have made a guideline for radiopharmaceuticals where stability is mentioned since the general stability guidelines are not fully applicable for ready-for-use radiopharmaceuticals, radionuclide generators and radioactive precursors. The most important aspects EMA mentions and should be taken into special consideration are: The minimum and maximum amount of concentration of radioactivity at the time of manufacture. The stability results should be presented on three batches, considered for the upper limit for a batch size. The specific characteristics for the radiopharmaceuticals decide the specification and test procedure. Testing frequency is based upon the shelf-life. For ready-for-use radiopharmaceuticals the shelf life after the time of manufacture should be established (European Medicines Agency 2009).

In their guidance for GMP for PET drugs, the US Food and Drug Administration (FDA) describes the test regimen that should be established, followed and maintained to determine the stability characteristics of an individual tracer. The methods used must be credible, meaningful and specific. Samples for stability tests must be representative of the batch from which they are taken and must be stored under suitable conditions. Test results must be documented and should be used to define sufficient storage conditions and expiration dates for each individual product produced (U.S. Food and Drug Administration 2011, 2015). The FDA's guideline for stability parameters includes radiochemical identity and purity (including levels of radiochemical impurities), visual control, $\mathrm{pH}$, and chemical purity, as well as possible control of stabilizer and/or preservative effect. It is recommended to use stability tests that can distinguish between impurities and degradation products. Furthermore, stability studies should be performed on the product with its highest radioactive concentration and in the correct volume for the final product in the intended packaging. A minimum of three productions of the finished product must be examined over a period of time corresponding to the applied shelf life (U.S. Food and Drug Administration 2011).

\section{Materials and methods}

\section{Literature study}

The non-systematic literature study was based on Ph. Eur 10.0., EMA guideline Q1A (R2) 3, the book Basic Science of PET Imaging (ICH 2003a; Khalil 2017), and the FDA's guidance for GMP and stability for PET drugs (U.S. Food and Drug Administration 2011, 2015), and was supplemented with an online non-systematic literature search performed using PubMed and Google Scholar as databases. The keywords used were FDG + Stability and the search was limited to contain keywords in title. Results were limited to studies published in English between 2009 and November 2021. Articles describing clinical findings were not included. Relevant references from the primary articles in the literature search were assessed and included if they contributed information that was relevant to this study.

\section{Experimental}

Experimental work was carried out at the PET-radiopharmaceutical production in The PET Imaging Centre, Dept. of Nuclear Medicine, University Hospital of Central Norway, 
Trondheim, Norway and at the PET-radiopharmaceutical production in The PET Imaging Centre, University Hospital of North Norway, Tromsø, Norway.

Both PET-production sites have undergone a full GMP validation recently, due to the build of completely new production facilities and is recognized as compliant by the Norwegian Health Agency, granting production licenses. Specifically for analytical methods, tests were carried out according to Ph.Eur when applies and in accordance with the $\mathrm{ICH}$ Q2 R1 (ICH 2003a).

In our two-centre stability study we examined the stability of $\left[{ }^{18} \mathrm{~F}\right] \mathrm{FDG}$ using the Füchtner`s modified Hamacher synthesis with basic hydrolysis. We studied the citrate buffered cassettes provided by GE Healthcare routinely used at production sites (Hamacher et al. 1986; Füchtner et al. 1996). Stability studies were performed on validated quality control equipment for $\left[{ }^{18} \mathrm{~F}\right] \mathrm{FDG}$ production.

\section{Chemicals}

$\left[{ }^{18} \mathrm{O}\right] \mathrm{H}_{2} \mathrm{O}$ water (enrichment $>98 \%$, GMP quality) was purchased from Rotem $\mathrm{GmbH}$ (Israel). MilliQ (type 1) water was used. All synthesis cassettes, dispensing kits were purchased from GE Healthcare. Standards such as FDG, FDM and Glucopyranose were purchased from ABX Advanced Biochemical Compounds GmbH (Germany). All other chemicals were purchased from VWR (Norway) and grade was analytical or better. All reagents and materials were handled according to GMP.

\section{$\left[{ }^{18} \mathrm{~F}\right] \mathrm{FDG}$ synthesis}

In short, $\left[{ }^{18} \mathrm{~F}\right] \mathrm{FDG}$ was prepared by the Füchtner's modified Hamacher method in an automated synthesis module (GE FASTLab2) in a hot cell. The synthesis in general can be described as follows: $\left[{ }^{18} \mathrm{~F}^{-}\right]$fluoride ions was produced by bombardment of $\left[{ }^{18} \mathrm{O}\right]$ $\mathrm{H}_{2} \mathrm{O}$ using a GE PETrace $16.5 \mathrm{MeV}$ cyclotron. Water containing $\left[{ }^{18} \mathrm{~F}^{-}\right]$fluoride ions was trapped by an anion-exchange column and eluted by a mixture of aminopolyether (Kryptofix) and potassium carbonate. Furthermore, the mixture was azeotropically dried by the addition of acetonitrile, heating, addition of pressure and flow of nitrogen. The reaction was heated for the nucleophilic substitution of $\left[{ }^{18} \mathrm{~F}^{-}\right]$fluoride ions on the mannose triflate. Preliminary purification was performed by passing the mixture thorough a column and washed with water several times. The retained intermediate was then deprotected using basic hydrolysis by sodium hydroxide at ambient temperature. The alkaline solution was then $\mathrm{pH}$-adjusted with hydrochloric acid and sodium citrate. Purification was performed with a reverse phase column (Sep-Pak C18) and an alumina cartridge. The purified product was collected through a $0.22 \mu \mathrm{m}$ filter in sterile glass vials into a lead/wolfram (Tungsten) container (Füchtner et al. 1996). The synthesis had a combined decay corrected radiochemical yield of $81.4 \% \pm 4.6 \%$ from end of bombardment (EOB) to end of synthesis (EOS).

\section{Stability studies}

The two different PET centers applied the same stability parameters for their $\left[{ }^{18} \mathrm{~F}\right] \mathrm{FDG}$ stability studies. In general, the quality analysis included 5 QC samples of $1 \mathrm{~mL}$. A full QC analysis was performed and included all stability tests at time points 0 and at 12 hours. Additionally, at time point 12 hours, the full patient vial was tested (12 mL), 20 
$\mathrm{mL}$ is the maximum recommended dose in milliliters $(\mathrm{V})$ as defined by Ph. Eur. Reasons for not evaluating a full patient vial for all test timepoints were related to the ALARA (as low as reasonably achievable) principle for radiation protection. At time points 3, 6 and 9 hours a reduced QC was undertaken, using HPLC (chemical identity), pH, HPLC (FDG in product), residual solvents (ethanol and acetonitrile), sterility, HPLC (radiochemical purity), HPLC ( $\left.\left[{ }^{18} \mathrm{~F}\right] \mathrm{FDM}\right)$, TLC (other radiochemical impurities and TLC (Radiochemical purity $\left.\left[{ }^{18} \mathrm{~F}\right] \mathrm{FDG}+\left[{ }^{18} \mathrm{~F}\right] \mathrm{FDM}\right)$. AT the time points 3,6 and 9 hours visual control, MCA for radionuclide identity $\left[{ }^{18} \mathrm{~F}\right]$ fluoride, radionuclide half-life $t \quad 1 / 2$, spottest for kryptofix, endotoxins and MCA for radionuclide purity $\left[{ }^{18} \mathrm{~F}\right]$ fluoride were excluded as they seemed redundant and unnecessary as evaluated by our quality risk assessment at the two centres. The activity to be tested was $4 \mathrm{GBq} / \mathrm{mL}$ EOS for both production sites. We used $160 \mathrm{GBq}$ (Trondheim) and 175-178 GBq (Tromsø) at EOB to have room for higher activities when asked for. In the preceding processes of validation, the $\mathrm{PQ}$, there was performed testing using a bracketing approach of high and low activity in order to obtain a robust product process, satisfying the clinical demand and leave a good margin for QC to work with. In the stability studies we opted for a high EOB activity, to be able to deliver higher activities when asked for. Production details from the PET centers in Trondheim and Tromsø are given in Table 1.

\section{$\left[{ }^{18} \mathrm{~F}\right] \mathrm{FDG}$ quality controls}

HPLC analysis was performed on an Agilent 1260 Infinity II BioInert HPLC equipped with a LabLogic LogiCHROM ECD detector and a LabLogic FlowRAM radiodetector, controlled with Laura software V.5. The analysis was performed by $20 \mu \mathrm{L}$ injections on a Dionex $4 \times 250 \mathrm{~mm}$ CarboPac PA10 column with CarboPac $4 \times 50 \mathrm{~mm}$ guard at $25^{\circ} \mathrm{C}$ using $0.1 \mathrm{M} \mathrm{NaOH}$ isocratic gradient with $1 \mathrm{~mL} / \mathrm{min}$ flow for $14 \mathrm{~min}$. System suitability test was performed with a solution of FDG and FDM standard in MilliQ water both with $25 \mu \mathrm{g} / \mathrm{mL}$ concentration.

TLC analysis for radiochemical purity was performed on Merck Silica gel $60 \mathrm{~F}_{254}$ $50 \times 100 \mathrm{~mm}$, developed over 9/10 of the plate with mobile phase 5:95 MilliQ:MeCN. $2 \mu \mathrm{L}$ QC-sample was added to the plate. For the system suitability test a $2 \mu \mathrm{L}$ solution of $30 \mathrm{mg} / \mathrm{mL} 1,2,3,4$-tetra-O-acetyl- $\beta$-D-glucopyranose standard (ABX) and $20 \mathrm{mg} / \mathrm{mL}$ Glucose standard (VWR) in MilliQ-water was added in a separate spot. Radiochromatogram was conducted using a LabLogic Dual ScanRAM radio TLC scanner followed by visualisation of the system suitability test using $75 \mathrm{~g} / \mathrm{L}$ sulphuric acid in $\mathrm{MeOH}$ developing and heat.

TLC analysis for impurity B, kryptofix was performed on Merck Silica gel $60 \mathrm{~F}_{254}$ $50 \times 20 \mathrm{~mm}$ pre-treated with Iodoplatinate reagent R1 (European pharmacopoeia) On the TLC plate $2.5 \mu \mathrm{L}$ of QC sample, MilliQ water, reference B (Ph. Eur.) and QC-sample + reference $\mathrm{B}$ (Ph. Eur.) was added in 4 separate spots and compared after drying.

GC-FID analysis was performed using an Agilent 7697A Headspace Sampler with Agilent 7820A Gas Chromatograph System equipped with a J\&W HP-INNOWax, 30 $\mathrm{m}, 0.32 \mathrm{~mm}, 0.25 \mu \mathrm{m}, \mathrm{GC}$ column. Analysis incorporated a validated short version of the Ph.Eur. method using $50{ }^{\circ} \mathrm{C}$ hold time $5 \mathrm{~min}$, ramping $30^{\circ} \mathrm{C} / \mathrm{min}$ to $120^{\circ} \mathrm{C}$, flow 3 $\mathrm{mL} / \mathrm{min}$. Helium gas as a mobile phase with inj.port $140{ }^{\circ} \mathrm{C}$ and FID $250{ }^{\circ} \mathrm{C}$. HS settings were preconditioning $80{ }^{\circ} \mathrm{C}$ for $15 \mathrm{~min}$, loop $90{ }^{\circ} \mathrm{C}$, transfer line $100{ }^{\circ} \mathrm{C}\left(105^{\circ} \mathrm{C}\right.$ 
Table 1 Production details from the PET-centers in Trondheim and Troms $\varnothing$

\begin{tabular}{|c|c|c|c|c|c|c|}
\hline \multirow{2}{*}{$\begin{array}{l}\text { Production } \\
\text { details }\end{array}$} & \multicolumn{6}{|l|}{ Batch } \\
\hline & $\begin{array}{l}\text { FDG191211015 } \\
\text { (Trondheim) }\end{array}$ & $\begin{array}{l}\text { FDG191212016 } \\
\text { (Trondheim) }\end{array}$ & $\begin{array}{l}\text { FDG200114004 } \\
\text { (Trondheim) }\end{array}$ & $\begin{array}{l}\text { FDG210824 } \\
\text { (Tromsø) }\end{array}$ & $\begin{array}{l}\text { FDG210901 } \\
\text { (Tromsø) }\end{array}$ & $\begin{array}{l}\text { FDG211012 } \\
\text { (Tromsø) }\end{array}$ \\
\hline $\begin{array}{l}\text { EOB activity } \\
\text { (GBq) }\end{array}$ & 160 & 160 & 160 & 175 & 176 & 178 \\
\hline $\begin{array}{l}\text { Mean target } \\
\text { current }\end{array}$ & 47.42 & 48.8 & 46.86 & 41.37 & 44.96 & 50.64 \\
\hline $\begin{array}{l}\text { Timepoint } \\
\text { EOS }\end{array}$ & 07:29:37 & 07:28:30 & 07:28:45 & 07:24:06 & $07: 25: 27$ & 07:23:53 \\
\hline $\begin{array}{l}\text { Timepoint } \\
\text { bulk measure- } \\
\text { ment }\end{array}$ & 07:47:32 & 07:38:28 & 07:35:10 & 07:30:14 & 07:31:41 & 07:29:45 \\
\hline $\begin{array}{l}\text { Activity in } \\
\text { bulk (GBq) }\end{array}$ & 96.06 & 103,586 & 99.47 & 117.14 & 120.37 & 108.49 \\
\hline $\begin{array}{l}\text { Volume bulk } \\
(\mathrm{mL})\end{array}$ & 19.33 & 20,33 & 22.29 & 21.79 & 21.49 & 21.28 \\
\hline $\begin{array}{l}\text { Concentration } \\
\text { in bulk at EOS } \\
(\mathrm{GBq} / \mathrm{mL}), \\
\text { pre-dilution }\end{array}$ & 5.56 & 5,43 & 4,65 & 5.59 & 5.83 & 5.29 \\
\hline $\begin{array}{l}\text { Timepoint } \\
\text { measured } \\
\text { patient vial }\end{array}$ & 08:13:08 & 08:08:07 & $08: 25: 37$ & 07:54:41 & $07: 58: 23$ & 07:52:58 \\
\hline $\begin{array}{l}\text { Activity } \\
\text { patient vial } \\
\text { (GBq) }\end{array}$ & 37.09 & 40.3 & 36.52 & 37.21 & 36.82 & 38.38 \\
\hline $\begin{array}{l}\text { Volume } \\
\text { patient vial } \\
(\mathrm{mL})\end{array}$ & 11.7 & 12.32 & 12.46 & 10,7 & 10,14 & 10,09 \\
\hline $\begin{array}{l}\text { Concentration } \\
\text { patient vial } \\
\text { at EOS (GBq/ } \\
\mathrm{mL})\end{array}$ & 4.17 & 4.20 & 4.20 & 4.22 & 4.47 & 4.57 \\
\hline $\begin{array}{l}\text { Concentration } \\
\text { patient vial } \\
\text { at dispensing } \\
\text { (GBq/mL) }\end{array}$ & 3.17 & 3.27 & 2.93 & 3.48 & 3.63 & 3.80 \\
\hline
\end{tabular}

Pre-dilution is fixed at $1 \mathrm{~mL}$

PET centre in Troms $\varnothing)$. The injection volume was $1000 \mu \mathrm{L}$. Split mode, split ratio 10:1 (5:1 PET centre in Tromsø). System suitability was performed running 3 samples containing $50 \mu \mathrm{L}$ solution of $\mathrm{ACN} 0.04 \%$ and $\mathrm{EtOH} 0.5 \%$ diluted to $5000 \mu \mathrm{L}$ with MilliQ-water. A $50 \mu \mathrm{L}$ QC sample was also diluted to $5000 \mu \mathrm{L}$ volume with MilliQ-water before analysis.

Bacterial endotoxins were determined on an Endosafe Nexgen PTS by Charles River Laboratories using FDA approved Endosafe PTS cartridges with $0.05 \mathrm{EU} / \mathrm{mL}$ sensitivity. The QC samples were diluted 1:50 (20 $\mu \mathrm{L}$ (QC-sample) in $980 \mu \mathrm{L}$ LAL reagent water). Twenty-five $\mu \mathrm{L}$ was added to the four wells on the cartridge in the Endosafe Nexgen PTS.

MCA analysis was performed using Mirion Canberrra Osprey MCA, equipped with Genie $2 \mathrm{~K}$ software and Laura. Two $\mu \mathrm{l}$ in an Eppendorf tube from a dilution of $20 \mu \mathrm{L} \mathrm{QC}$ sample in $980 \mu \mathrm{L}$ MilliQ water type 1 was added to the MCA and analysed immediately and after 24 hours.

The half-life was measured on the dose calibrator (Capintec CRC-55t-PET). The QC sample was placed in the dose calibrator and measured. 
The $\mathrm{pH}$-measurement for the QC-sample was performed on a Mettler Toledo Seven Excellence $\mathrm{pH}$-meter with a Mettler Toledo Inlab Ultra Micro-ISM pH-electrode first calibrated by the buffer solutions $\mathrm{pH} 4.01,7.00$ and 9.21 .

A total of $5 \mathrm{QC}$ samples with aliquots of $1 \mathrm{~mL}$ in separate tungsten containers and 1 full patient vial $12 \mathrm{~mL}$ in tungsten container was used for each experiment. The experiments were performed three times at both production sites. Acceptance criteria for the different tests are given in Table 3.

\section{Results}

The primary literature search described in the method section resulted in the inclusion of 6 articles. The PubMed search identified 157 articles, 5 of which were relevant for the stability of $\left[{ }^{18} \mathrm{~F}\right] \mathrm{FDG}$. Fourteen articles were found using Google Scholar, 4 of which were relevant for the stability of $\left[{ }^{18} \mathrm{~F}\right] \mathrm{FDG}$, Table 2 . Of these, one article did not appear in the PubMed search. Table 2 summarizes the results of the search of the primary literature. These sources were also assessed and included in the literature study if they contributed important information in relation to the study (Table 2).

Sixteen articles were reviewed in this literature study. Table 3 summarizes the most important studies, data for activity, ethanol content (as a stabilizer), temperature used for the stability study, reference work/quality requirements and found durability.

The $\left[{ }^{18} \mathrm{~F}\right]$ FDG produced at the two different PET centres was tested for stability as described earlier at the given time points: 0, 3, 6, 9 and 12 hours. All acceptance criteria were met for the two production sites for the production of $\left[{ }^{18} \mathrm{~F}\right] \mathrm{FDG}$ at time points 0,3 , 6, 9 and 12 hours. Results from timepoint $12 \mathrm{~h}$ EOS from both production sites are gives as examples, see Table 4 showing tests performed, acceptance criteria and results.

\section{Discussion}

PET radiopharmaceuticals have a short shelf life due to the short half-life of the PET radionuclides. However, due to stability issues and especially radiation-related radiolysis of the active substance and solvent, it is still important to evaluate several stability parameters in the product's lifetime (ICH 2003b; U.S. Food and Drug Administration 2011). Herein we discuss legislation, guidelines, recommendations, limitations, literature, and our own two-centre stability studies.

After reviewing guidelines and recommendations such as the USP, Ph. Eur., and guidelines from the national regulatory authorities in Norway, the FDA and the EMA we found several important aspects of stability to evaluate. The FDA's guidelines suggest specific stability parameters to be checked in such a study of radiopharmaceuticals, which contrasts with the EMA, which describes stability studies more generally for all current/marketed and future drugs (ICH 2003a; b). EMA describes stability studies of finished products:

- Considerations should be made based on the literature and experience with the active substance and its properties. This includes assessments from stability data on the active substance and evidence from clinical formulation studies.

- Testing for photostability 
Table 2 Results from the primary literature study and relevant references

\begin{tabular}{|c|c|c|c|c|}
\hline Study & Year & Title & Relevant references & References \\
\hline Ferreira & 2009 & $\begin{array}{l}\text { Stability study of 2-[18 } \mathrm{F}] \\
\text { fluoro-2-deoxy-D-glucose } \\
\left(\left[^{18} \mathrm{~F}\right] \mathrm{FDG}\right) \text { stored at room } \\
\text { temperature by physico- } \\
\text { chemical and microbiologi- } \\
\text { cal assays }\end{array}$ & Fawdry (2007) & Ferreira et al. (2009) \\
\hline Hjelstuen & 2011 & $\begin{array}{l}\text { Standardization of } \\
\text { fluorine-18 manufacturing } \\
\text { processes: New scientific } \\
\text { challenges for PET }\end{array}$ & Jacobson et al. (2009) & Hjelstuen et al. (2011) \\
\hline Walters & 2011 & $\begin{array}{l}\text { Stability evaluation of }\left[{ }^{18} \mathrm{~F}\right] \\
\text { FDG at high radioactive } \\
\text { Concentrations }\end{array}$ & $\begin{array}{l}\text { Jacobson et al. (2009), Faw- } \\
\text { dry (2007), Yu (2006) }\end{array}$ & Walters et al. (2011) \\
\hline Dantas & 2013 & $\begin{array}{l}\text { Radiolysis of 2-[ }\left[{ }^{18} \mathrm{~F}\right] \text { fluoro- } \\
\text { 2-deoxy-D-glucose }\left(\left[{ }^{18} \mathrm{~F}\right]\right. \\
\text { FDG) and the role of ethanol, } \\
\text { radioactive concentration } \\
\text { and temperature of storage }\end{array}$ & Jacobson et al. (2009) & Dantas et al. (2013) \\
\hline Rahmani & 2017 & $\begin{array}{l}\text { Synthesis, quality control } \\
\text { and stability studies of } \\
\left.2-{ }^{18} \mathrm{~F}\right] \mathrm{Fluoro}-2-D e o x y-D- \\
\text { Glucose }\left({ }^{18} \mathrm{~F}-\mathrm{FDG}\right) \text { at different } \\
\text { conditions of temperature } \\
\text { by physicochemical and } \\
\text { microbiological assays }\end{array}$ & $\begin{array}{l}\text { Hamacher et al. (1986), } \\
\text { Hung (2002), Fawdry (2007), } \\
\text { Ferreira et al. (2009), Yu } \\
\text { (2006) }\end{array}$ & Rahmani et al. (2017) \\
\hline Joszai & 2019 & $\begin{array}{l}\text { Recommendations for } \\
\text { selection of additives for } \\
\text { stabilization of }\left[{ }^{18} \mathrm{~F}\right] \mathrm{FDG}\end{array}$ & $\begin{array}{l}\text { Hamacher et al. (1986), } \\
\text { Dantas et al. (2013), Meyer } \\
\text { et al. (1999), Fawdry (2007), } \\
\text { Jacobson et al. (2009), } \\
\text { Rensch et al. (2012), Kiselev } \\
\text { et al. (2006), Mosdzianowski } \\
\text { et al. (2002) }\end{array}$ & Jószai et al. (2019) \\
\hline Hamacher & 1986 & $\begin{array}{l}\text { Efficient stereospecific syn- } \\
\text { thesis of no-carrier-added } \\
2-\left[^{18} \mathrm{~F}\right] \text {-Fluoro-2-Deoxy-D- } \\
\text { Glucose using aminopoly- } \\
\text { ether supported nucleo- } \\
\text { philic substitution }\end{array}$ & & Hamacher et al. (1986) \\
\hline Meyer & 1999 & $\begin{array}{l}\text { The stability of 2-[18} \text { F]fluoro- } \\
\text { 2-deoxy-D-glucose towards } \\
\text { epimerisation under alkaline } \\
\text { conditions }\end{array}$ & & Meyer et al. (1999) \\
\hline Hung & 2002 & $\begin{array}{l}\text { Comparison of various } \\
\text { requirements of the quality } \\
\text { assurance procedures for } \\
{\left[{ }^{18} \mathrm{~F}\right] \mathrm{FDG} \text { injection. }}\end{array}$ & & Hung (2002) \\
\hline Kiselev & 2002 & $\begin{array}{l}\text { Stabilization of radiophar- } \\
\text { maceuticals labelled with } \\
{\left[{ }^{18} \text { F]fluoride. US Patent }\right.}\end{array}$ & & Kiselev et al. (2006) \\
\hline Mosdzianowski & 2002 & $\begin{array}{l}\text { Epimerization study on }\left[{ }^{18} \mathrm{~F}\right] \\
\text { FDG produced by an alkaline } \\
\text { hydrolysis on solid support } \\
\text { under stringent conditions }\end{array}$ & & Mosdzianowski et al. (2002) \\
\hline Yu & 2006 & $\begin{array}{l}\text { Review of }\left[{ }^{18} \mathrm{~F}\right] \mathrm{FDG} \text { synthesis } \\
\text { and quality control }\end{array}$ & & Yu (2006) \\
\hline Fawdry & 2007 & $\begin{array}{l}\text { Radiolysis of 2- }\left[{ }^{18} \mathrm{~F}\right] \text { fluoro- } \\
2 \text {-deoxy-D-glucose }\left(\left[^{18} \mathrm{~F}\right]\right. \\
\text { FDG) and the role of reduct- } \\
\text { ant stabilisers }\end{array}$ & & Fawdry (2007) \\
\hline
\end{tabular}


Table 2 (continued)

\begin{tabular}{|c|c|c|c|c|}
\hline Study & Year & Title & Relevant references & References \\
\hline Jacobson & 2009 & $\begin{array}{l}\text { Radiolysis of } 2-\left[{ }^{18} \mathrm{~F}\right] \text { fluoro- } \\
\text { 2-deoxy-D-glucose }\left(\left[{ }^{18} \mathrm{~F}\right]\right. \\
\text { FDG }) \text { and the role of ethanol } \\
\text { and radioactive concentra- } \\
\text { tion }\end{array}$ & & Jacobson et al. (2009) \\
\hline Rensch & 2012 & $\begin{array}{l}\text { Microfluidic reactor geom- } \\
\text { etries for radiolysis reduction } \\
\text { in radiopharmaceuticals }\end{array}$ & & Rensch et al. (2012) \\
\hline Long & 2013 & $\begin{array}{l}\text { Comparison of FASTlab } \\
{\left[{ }^{18} \mathrm{~F}\right] \mathrm{FDG} \text { production using }} \\
\text { phosphate and citrate buffer } \\
\text { cassettes }\end{array}$ & & Long et al. (2013) \\
\hline
\end{tabular}

Table 3 Overview of stability studies with activity investigated, temperature, amount of ethanol, quality references and shelf life.

\begin{tabular}{|c|c|c|c|c|c|}
\hline Study & Activity $\mathrm{GBq} / \mathrm{mL}$ & Temperature & Ethanol (\%) & $\begin{array}{l}\text { Quality } \\
\text { references }\end{array}$ & Shelf life \\
\hline $\begin{array}{l}\text { Ferreira et al. } \\
\text { (2009) }\end{array}$ & $0.3-0.7$ & $\mathrm{RT}\left(22^{\circ} \mathrm{C}\right)$ & $\approx 0.04$ & USP 31 & $10 \mathrm{~h}$ \\
\hline $\begin{array}{l}\text { Walters et al. } \\
\text { (2011) }\end{array}$ & 19.7-22.6 EOS & - & 0.2 & USP 34 & $12 \mathrm{~h}$ \\
\hline $\begin{array}{l}\text { Dantas et al. } \\
\text { (2013) }\end{array}$ & $0.7-4.8$ & $5,25,40^{\circ} \mathrm{C}$ & $0.1-0.4$ & Ph. Eur. 7ed & $16 \mathrm{~h}$ \\
\hline $\begin{array}{l}\text { Rahmani et al. } \\
\text { (2017) }\end{array}$ & $0.3-0.5$ & $\begin{array}{l}18-23^{\circ} \mathrm{C} \\
35-40^{\circ} \mathrm{C}\end{array}$ & $0.012 \mathrm{mg} / \mathrm{mL}$ & Ph. Eur. 7ed & $10 \mathrm{~h}$ \\
\hline $\begin{array}{l}\text { Jószai et al. } \\
\text { (2019) }\end{array}$ & 2 and 15 & RT & $50 \mathrm{mmol} / \mathrm{L}$ & Ph. Eur. 9ed & $210 \mathrm{~min}$ or $15 \mathrm{~h}$ \\
\hline $\begin{array}{l}\text { Kiselev et al. } \\
\text { (2006) }\end{array}$ & - & - & $\begin{array}{l}\mathrm{min} .0 .01 \% / \mathrm{GBq} / \\
\mathrm{mL}\end{array}$ & - & - \\
\hline Fawdry (2007) & 6.3 and 11.5 & RT & 0.1 & BP 2005 & $14 \mathrm{~h}$ \\
\hline $\begin{array}{l}\text { Jacobson et al. } \\
\text { (2009) }\end{array}$ & up to 14.2 & - & 0.1 & Ph. Eur. 6ed & $10 \mathrm{~h}$ \\
\hline $\begin{array}{l}\text { Rensch et al. } \\
\text { (2012) }\end{array}$ & $4-23$ & - & - & - & $14 \mathrm{~h}$ \\
\hline Long et al. (2013) & $2.26-8.8$ & - & $0.2 \pm 0.07$ & USP 34 & - \\
\hline
\end{tabular}

- At least three units from different batches must be included in the stability study of the finished product, and this must be done for each of the strengths of the product to be marketed.

- The stability study must be performed on the product in the final packaging.

- A specification, namely a list of tests with associated requirements, shall be produced, and confirmed by the stability study. For stability studies of longer duration, there is a requirement to describe test frequency.

- Storage conditions must be specified and supported by the stability study. For studies of longer duration, beyond the time of marketing authorization, the manufacturer must commit to conducting long-term studies of stability. The stability study shall result in an evaluation, which, in addition to the test results for quality, includes degradation products and other relevant conditions that may affect the quality, safety and efficacy of the product. 
Holler et al. EJNMMI Radiopharmacy and Chemistry $\quad$ (2022) 7:2

Page 10 of 18

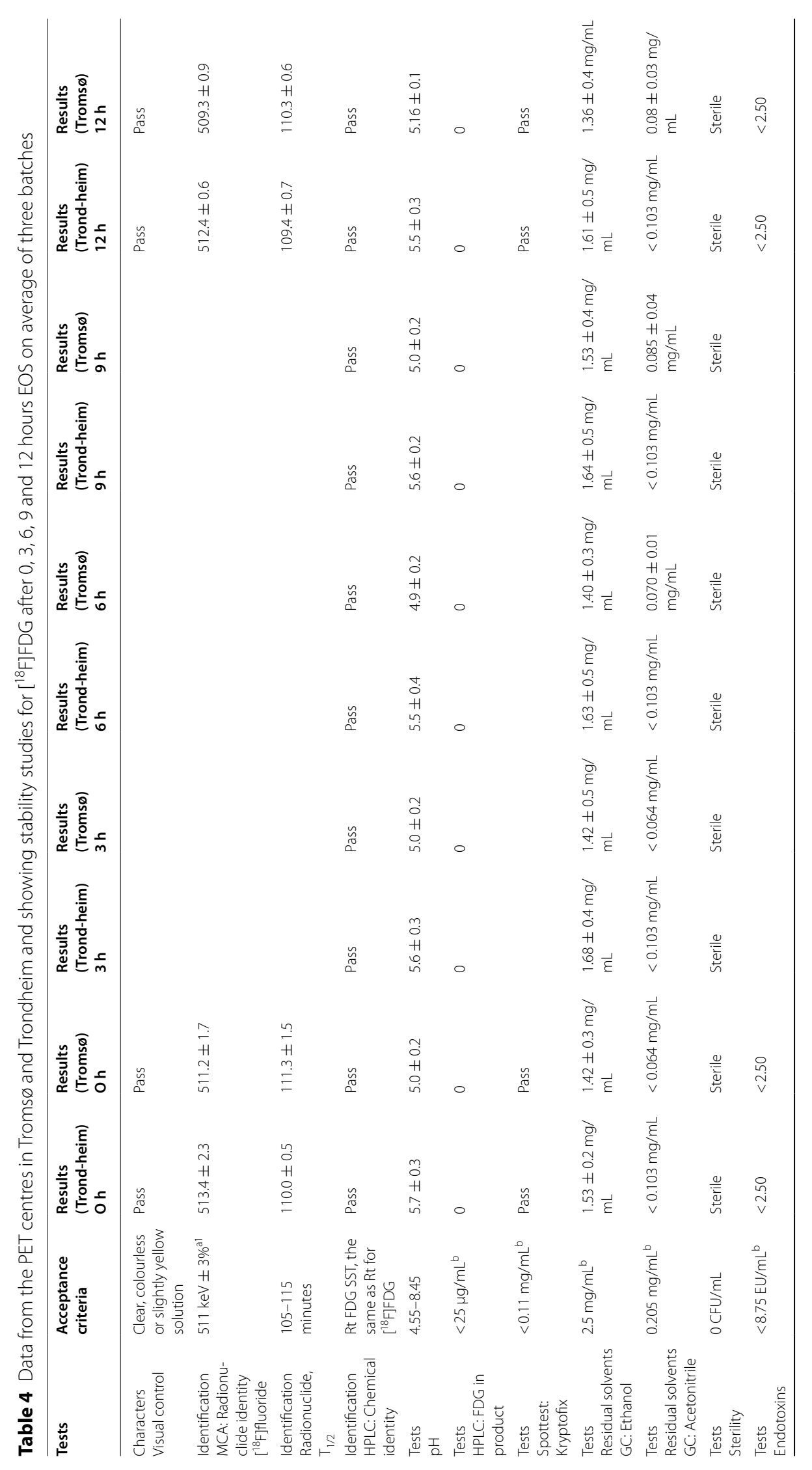




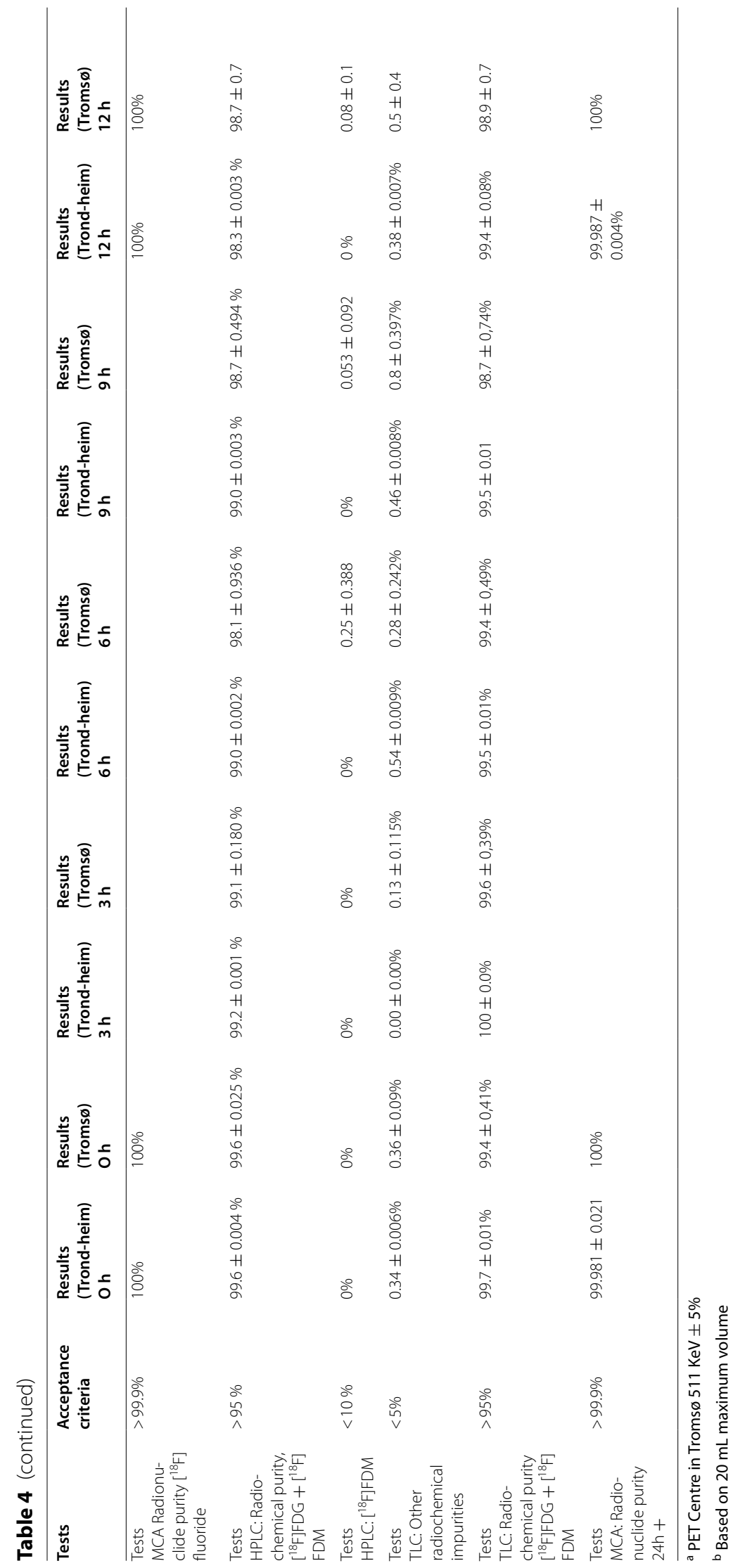


- Additionally, the product must have a storage guide for the packaging in line with national legislation (ICH 2003a). Storage instructions must be based on data from the stability study. The shelf life will then be defined as the maximum time the product can undergo quality control in accordance with the monograph with satisfactory results. Considerations should be given to which other aspects of storage may affect the shelf life of the product, including photostability, temperature, septum integrity, as well as instructions for use and labelling. The European Pharmacopoeia describes that a product must conform to the monograph throughout its life, which means that parts of the stability study can be carried out by repeated quality control of the product at set times after dispensing. The shelf life of the product will be accurate if it complies with the requirements set out in the pharmacopoeia, in addition to the other requirements described in the EMA guidelines (Council of Europe 2019; European Medicines Agency 2009).

For the stability evaluation of $\left[{ }^{18} \mathrm{~F}\right] \mathrm{FDG}$, some important precautions must be taken into consideration and may not apply to other sites; any deviation must be evaluated in a quality risk assessment. First, the $\left[{ }^{18} \mathrm{~F}\right] \mathrm{FDG}$ production followed GMP standards: validated production method, validated cleanroom, validated personnel working aseptically and with validated equipment. It means the environment is controlled; it is a cleanroom, where temperature (room temperature, $15-25^{\circ} \mathrm{C}$ ), microbiological contaminants and moisture are controlled. Additionally, the experimental study was carried out on fully validated equipment according to ICH Q2 R1 (ICH 2003a), ensuring confidence in reproducibility of the methods and quality of the experimental data. At both production sites, experimental data revealed that the stability for $\left[{ }^{18} \mathrm{~F}\right] \mathrm{FDG}$ is suitable and accepted for all tests at the time points $0,3,6,9$ and 12 hours with the given radio-stabilizer ethanol with $4 \mathrm{GBq} / \mathrm{mL}$ activity. As expected, we saw less radiochemical purity at high starting activities and low dilution volumes, however as mentioned the stability was found suitable even at high EOB starting activity. The product ( $\left.\left[{ }^{18} \mathrm{~F}\right] \mathrm{FDG}\right)$ is documented thoroughly in the literature and is thus a well-known drug. Its photostability was not evaluated as it was considered irrelevant for this study since the product is kept in a container (lead/wolfram(tungsten)) protected from light and is only exposed to light when it is transferred from the container to the injection module right before being injected into patients. Likewise, the sterile evaluation of the multidose withdrawal from each vial was not evaluated since, in our case, the injection into patients was performed by the automated Posijet module. However, sterility can be maintained over multiple withdrawals, even over several days, using sterile techniques (Gallardo et al. 2015). There is also a risk for microbial growth can occur at room temperature vs. at lower temperatures at for instance 2-8 degrees Celsius. Also, residual glucose from the synthesis in the final product can provide nutrition for potential microbiota. However, the product is supposed to be sterile at delivery, the product is tested for sterility even though the result is not known at the time of release. The risk-assessment and validation of the production must ensure that the production method and dispensing is indeed an aseptic process. The final dispensing step is done using sterile filtration and aseptic procedures. Ethanol in the concentrations used in the FDG-production has no or very limited conservational effects on microbiota. Dantas et al. (2013) investigated whether sterility was maintained 
during repeated withdrawal from a multidose vial containing $\left[{ }^{18} \mathrm{~F}\right] \mathrm{FDG}$ and found that this practice does not pose a risk to the patient as long as it is performed according to aseptic technique with the right sterile equipment. Furthermore, for our stability studies the activity was set to be $4 \mathrm{GBq} / \mathrm{mL}$ at EOS. The stability studies were performed within primary packaging, in our case a labelled vial with septum and cap. The acceptance criteria in our specifications are the same for release and for shelf-life acceptance and are given in Table 3. The acceptance criteria are based on ICH and GMP guidelines (ICH 2003a; U.S. Food and Drug Administration 2011). These criteria can be different for release and shelf-life considerations: for example, the amount of degradation can be different after release and after storage (ICH 2003a; b).

When we started this work it became clear that no updated overview of the stability literature for $\left[{ }^{18} \mathrm{~F}\right] \mathrm{FDG}$ was available. Therefore, the purpose of the non-systematic literature study was to get an overview of and updated information on the stability evaluations for $\left[{ }^{18} \mathrm{~F}\right] \mathrm{FDG}$. We also found some contradictions regarding activity and stabilization with stabilizers we wanted to examine. The starting point of the non-systematic literature study was to find relevant information in relation to PET radiopharmaceutical production and $\left[{ }^{18} \mathrm{~F}\right] \mathrm{FDG}$. The literature search was limited to publications in English from the past 12 years that included "FDG" and "stability" in the title. Additionally, literature containing $\left[{ }^{18} \mathrm{~F}\right] \mathrm{FDG}$ prepared by the Hamacher synthesis by nucleophilic substitution was included. These parameters limited the literature study. However, the purpose of the study was to get an overview and updated information. Furthermore, the relevant references from the primary articles provided deeper insight into the stability of $\left[{ }^{18} \mathrm{~F}\right] \mathrm{FDG}$ and were found to be sufficient for this literature study. All sixteen studies are listed in Table 2.

It is well known that the major stability issue for radiopharmaceuticals is radiolysis which can be either autoradiolysis, self-destruction by its own radiation, and/or attack by free radicals formed by the radiation on environmental species. The radiolysis, or more specifically autoradiolysis, of $\left[{ }^{18} \mathrm{~F}\right] \mathrm{FDG}$ mainly results in free $\left[{ }^{18} \mathrm{~F}^{-}\right]$fluoride ions (Jószai et al. 2019). The radiolysis of $\left[{ }^{18} \mathrm{~F}\right] \mathrm{FDG}$ also generates free radicals because of the reaction of ionizing radiation with water (Buriova et al. 2005). Additionally, Buriova et al. reported two other impurities after autoradiolysis during the synthesis of $\left[{ }^{18} \mathrm{~F}\right]$ FDG. They were identified as $2-\left[{ }^{18} \mathrm{~F}\right]$ fluoroglucuronic acid and $2-\left[{ }^{18} \mathrm{~F}\right]$ fluorogluconic acid and are products of autoradiolysis. However, they counted for less than $1.3 \%$ of the total activity (Buriova et al. 2005). There are several strategies to reduce radiolysis: one common and well documented strategy is to stabilize with radio-stabilizers. The most well-known and frequently used radio-stabilizer is ethanol. Dantas et al. (2013) found that ethanol content of $0.1-0.4 \%$ was sufficiently stable hours in terms of radiochemical purity for up to 16 . However, no correlation was found between ethanol concentration and radiochemical purity. This contrasts with Jacobson et al. (2009). Similar to Fawdry (2007) and Jacobson et al. (2009), Dantas et al. (2013) showed that the degradation of $\left[{ }^{18} \mathrm{~F}\right] \mathrm{FDG}$ to free $\left[{ }^{18} \mathrm{~F}^{-}\right]$fluoride ions increases until approx. $4 \mathrm{~h}$ EOS, after which the increase due to radiolysis is offset by the decay of $\left[{ }^{18} \mathrm{~F}\right]$ fluoride and stabilizes at approx. $2 \%$. Walters et al. (2011) found that $0.2 \%$ ethanol was needed to keep batches with activity of $19.7-22.6 \mathrm{GBq} / \mathrm{mL}$ stable for up to 12 hours after EOS. Moreover, batches of $0.1 \%$ and $0.0 \%$ ethanol failed radiochemical 
purity for such high activity $(19.7-22.6 \mathrm{GBq} / \mathrm{mL}) 5$ hours and 1 hour, respectively, after EOS. Walters et al. tested their batches according to the USP, which allows a radiochemical purity og $>90 \%$. On average $6 \%$ impurities were found at 12 hours post EOS. In our own two-centre stability studies, the ethanol content was set to contain a minimum of $0.1 \%$ after 12 hours with the activity of $4 \mathrm{GBq} / \mathrm{mL}$. In a patent registered in the USA, Kiselev et al. (2006) describe that the concentration of ethanol should be $0.01 \% / \mathrm{GBq} / \mathrm{mL}$. Mosdzianowski et al. (2002) found that ethanol in $0.1 \%$ concentration did not have a significant effect on the stability of $\left[{ }^{18} \mathrm{~F}\right] \mathrm{FDG}$ batches with an activity between 6.3 and $11.5 \mathrm{GBq} / \mathrm{mL}$. In contrast, Jacobson et al. (2009) found that $0.1 \%$ ethanol can stabilize batches with activity up to $14.2 \mathrm{GBq} / \mathrm{mL}$ for up to $10 \mathrm{~h}$. In another study, Jószai et al. (2019) examined the effect of various stabilizers and found that hydroxyl $(\mathrm{OH} \cdot)$ radicals play a crucial role in the radiolysis of $\left[{ }^{18} \mathrm{~F}\right] \mathrm{FDG}$ and that selective $\mathrm{OH}$. scavengers, such as salicylate, glucose, cysteine and pantothenic acid are good stabilizers. The concentration should be at least $50 \mathrm{mmol} / \mathrm{L}$. Jószai suggests glucose is ideal for stabilizing $\left[{ }^{18} \mathrm{~F}\right] \mathrm{FDG}$ and found $>98 \%$ radiochemical purity after 15 hours. Interestingly, Long et al. (2013), investigated the difference between GE Healthcare FASTLab reagent kits with phosphate and citrate buffer in the synthesis. A higher ethanol content was found in the cassettes with the citrate buffer, and it was concluded that this is better in terms of the stability of the product.

Dantas et al. (2013) studied the stability of $\left[{ }^{18} \mathrm{~F}\right] \mathrm{FDG}$ at three different temperatures, 5, 25 and $40^{\circ} \mathrm{C}$, every two hours for 16 hours. They found that the temperature had no effect on the degradation. Additionally, Ferreira et al. (2009) showed that $\left[{ }^{18} \mathrm{~F}\right] \mathrm{FDG}$ batches with an activity of $0.3-0.7 \mathrm{GBq} / \mathrm{mL}$ are stable for up to 10 hours at room temperature under experimental conditions. The quality requirements that were used as a basis are USP 317. Rahmani et al. (2017) describes that a $\left[{ }^{18} \mathrm{~F}\right] \mathrm{FDG}$ batch produced with cassettes from ABX at TracerLab and analysed according to Ph. Eur. 7 is stable for up to 10 hours, at room temperature and elevated temperature $\left(35-40{ }^{\circ} \mathrm{C}\right)$.

The dilution factor for the product as a stabilizer must also be considered. Jiménez Romero et al. (2006) recommend physiological saline dilution of $\left[{ }^{18} \mathrm{~F}\right] \mathrm{FDG}$ preparations. They found a significant difference in the amount of $\left[{ }^{18} \mathrm{~F}\right]$ fluoride in undiluted versus diluted product in studies in the period between $30 \mathrm{~min}$ and $5 \mathrm{~h}$. Hjelstuen et al. (2011) recommends keeping the radioactivity level as low as possible and performing the dilution immediately after EOS; the dilution has limitations due to the maximum volume to be injected, and additionally a radio-stabilizer can be considered.

There have been constant developments in the synthesis of $\left[{ }^{18} \mathrm{~F}\right] \mathrm{FDG}$ which have improved synthesis, especially with regard to yield and time. Interestingly, Mosdzianowski et al. (2002) investigated whether $\mathrm{pH}$ and temperature, as well as the time for the hydrolysis of Acetyl-FDG, have an effect on the amount of $\left[{ }^{18} \mathrm{~F}\right] \mathrm{FDG}$ formed in the synthesis. They found up to approx. $7 \%\left[{ }^{18} \mathrm{~F}\right] \mathrm{FDM}$ at extended hydrolysis time (15 $\left.\mathrm{min}\right), 2 \mathrm{~N}$ $\mathrm{NaOH}$ and $60^{\circ} \mathrm{C}$, which is still within the requirements of Ph. Eur. Furthermore, Meyer et al. (1999) found that using $0.33 \mathrm{M} \mathrm{NaOH}, 40{ }^{\circ} \mathrm{C}$ reaction temperature and up to $5 \mathrm{~min}$ reaction time reduced the epimerization (conversion) of $\left[{ }^{18} \mathrm{~F}\right] \mathrm{FDG}$ to $\left[{ }^{18} \mathrm{~F}\right] \mathrm{FDM}$ to $0.5 \%$. In addition, Rensch et al. (2012) investigated the use of microcapillaries to store $\left[{ }^{18} \mathrm{~F}\right]$ FDG without high activity stabilization to avoid autoradiolysis and found up to $>80 \%$ radiochemical purity for up to 14 hours after EOS for activities from 4 to $23 \mathrm{GBq} / \mathrm{mL}$. 
The experimental study at both production sites revealed that the stability for $\left[{ }^{18} \mathrm{~F}\right]$ FDG is suitable and accepted for all tests at the time points $0,3,6,9$ and 12 hours with the given radio-stabilizer ethanol with $4 \mathrm{GBq} / \mathrm{mL}$ activity. In accordance with the quality risk evaluations and also based on the ALARA full QC tests were performed at $\mathrm{o}$ and 12 hours as listed in Table 5. Reduced QC-tests were performed at time points 3, 6 and 9 hours, as listed in Table 5. Another stability parameter that was excluded was the temperature since the product is kept stable at room temperature at hospital settings. Therefore, no temperature variations were included. Dantas et al. (2013) and Rahmani et al. (2017) tested different temperatures and found the $\left[{ }^{18} \mathrm{~F}\right]$ FDG stable for $5-40{ }^{\circ} \mathrm{C}$, as mentioned previously.

For future $\left[{ }^{18} \mathrm{~F}\right] \mathrm{FDG}$ implementation, we present some recommendations based on the non-systematic literature study and the two experimental stability studies.

Table 5: List of QC stability tests performed at the two production sites.

\begin{tabular}{|c|c|c|c|c|c|}
\hline & $\mathrm{Oh}$ & $3 \mathrm{~h}$ & $6 \mathrm{~h}$ & $9 \mathrm{~h}$ & $12 \mathrm{~h}$ \\
\hline Characters & Visual control & & & & Visual control \\
\hline Identification & $\begin{array}{l}\text { MCA: Radionu- } \\
\text { clide identity }\left[{ }^{[8} \mathrm{F}\right] \\
\text { fluoride }\end{array}$ & & & & $\begin{array}{l}\text { MCA: Radionu- } \\
\left.\text { clide identity }{ }^{18} \mathrm{~F}\right] \\
\text { fluoride }\end{array}$ \\
\hline Identification & $\begin{array}{l}\text { Radionuclide } \\
\text { identity, } T_{1 / 2}\end{array}$ & & & & $\begin{array}{l}\text { Radionuclide } \\
\text { identity, } T_{1 / 2}\end{array}$ \\
\hline Identification & $\begin{array}{l}\text { HPLC: Chemical } \\
\text { identity }\end{array}$ & $\begin{array}{l}\text { HPLC: Chemical } \\
\text { identity }\end{array}$ & $\begin{array}{l}\text { HPLC: Chemical } \\
\text { identity }\end{array}$ & $\begin{array}{l}\text { HPLC: Chemical } \\
\text { identity }\end{array}$ & $\begin{array}{l}\text { HPLC: Chemical } \\
\text { identity }\end{array}$ \\
\hline Tests & $\mathrm{pH}$ & $\mathrm{pH}$ & $\mathrm{pH}$ & $\mathrm{pH}$ & $\mathrm{pH}$ \\
\hline Tests & $\begin{array}{l}\text { HPLC: FDG in } \\
\text { product }\end{array}$ & $\begin{array}{l}\text { HPLC: FDG in } \\
\text { product }\end{array}$ & $\begin{array}{l}\text { HPLC: FDG in } \\
\text { product }\end{array}$ & $\begin{array}{l}\text { HPLC: FDG in } \\
\text { product }\end{array}$ & $\begin{array}{l}\text { HPLC: FDG in } \\
\text { product }\end{array}$ \\
\hline Tests & $\begin{array}{l}\text { Spottest: } \\
\text { Kryptofix }\end{array}$ & & & & Spottest: Kryptofix \\
\hline Tests & GC: ethanol & GC: ethanol & GC: ethanol & GC: ethanol & GC: ethanol \\
\hline Tests & GC: acetonitrile & GC: acetonitrile & GC: acetonitrile & GC: acetonitrile & GC: acetonitrile \\
\hline Tests & Sterility & Sterility & Sterility & Sterility & Sterility \\
\hline Tests & Endotoxins & & & & Endotoxins \\
\hline Tests & $\begin{array}{l}\text { MCA: Radionu- } \\
\text { clide purity }\left[{ }^{18} \mathrm{~F}\right] \\
\text { fluoride }\end{array}$ & & & & $\begin{array}{l}\text { MCA: Radionuclide } \\
\text { purity }\left[{ }^{18} \mathrm{~F}\right] \text { fluoride }\end{array}$ \\
\hline Tests & $\begin{array}{l}\text { TLC: Radiochemi- } \\
\left.\text { cal purity }{ }^{18} \mathrm{~F}\right] \\
\text { FDG }+\left[{ }^{18} \mathrm{~F}\right] \mathrm{FDM}\end{array}$ & $\begin{array}{l}\text { TLC: Radiochemi- } \\
\left.\text { cal purity }{ }^{18} \mathrm{~F}\right] \\
\text { FDG }+\left[{ }^{18} \mathrm{~F}\right] \mathrm{FDM}\end{array}$ & $\begin{array}{l}\text { TLC: Radiochemi- } \\
\left.\text { cal purity }{ }^{18} \mathrm{~F}\right] \\
\text { FDG }+\left[{ }^{18} \mathrm{~F}\right] \mathrm{FDM}\end{array}$ & $\begin{array}{l}\text { TLC: Radiochemi- } \\
\left.\text { cal purity }{ }^{18} \mathrm{~F}\right] \\
\text { FDG }+\left[{ }^{18} \mathrm{~F}\right] \mathrm{FDM}\end{array}$ & $\begin{array}{l}\text { TLC: Radiochemi- } \\
\text { cal purity }\left[{ }^{18} \mathrm{~F}\right] \mathrm{FDG} \\
+\left[{ }^{18} \mathrm{~F}\right] \mathrm{FDM}\end{array}$ \\
\hline Tests & HPLC: $\left[{ }^{18} \mathrm{~F}\right] \mathrm{FDM}$ & HPLC: $\left[{ }^{18} \mathrm{~F}\right] \mathrm{FDM}$ & HPLC: $\left[{ }^{18} \mathrm{~F}\right] \mathrm{FDM}$ & HPLC: $\left[{ }^{18} \mathrm{~F}\right] \mathrm{FDM}$ & HPLC: $\left[{ }^{18} \mathrm{~F}\right] \mathrm{FDM}$ \\
\hline Tests & $\begin{array}{l}\text { TLC: Other } \\
\text { radiochemical } \\
\text { impurities }\end{array}$ & $\begin{array}{l}\text { TLC: Other } \\
\text { radiochemical } \\
\text { impurities }\end{array}$ & $\begin{array}{l}\text { TLC: Other } \\
\text { radiochemical } \\
\text { impurities }\end{array}$ & $\begin{array}{l}\text { TLC: Other } \\
\text { radiochemical } \\
\text { impurities }\end{array}$ & $\begin{array}{l}\text { TLC: Other } \\
\text { radiochemical } \\
\text { impurities }\end{array}$ \\
\hline Tests & $\begin{array}{l}\text { TLC: Radiochemi- } \\
\text { cal purity }\left[{ }^{18} \mathrm{~F}\right] \\
\text { FDG }+\left[{ }^{18} \mathrm{~F}\right] \mathrm{FDM}\end{array}$ & $\begin{array}{l}\text { TLC: Radiochemi- } \\
\left.\text { cal purity }{ }^{18} \mathrm{~F}\right] \\
\text { FDG }+\left[{ }^{18} \mathrm{~F}\right] \mathrm{FDM}\end{array}$ & $\begin{array}{l}\text { TLC: Radiochemi- } \\
\left.\text { cal purity }{ }^{18} \mathrm{~F}\right] \\
\text { FDG }+\left[{ }^{18} \mathrm{~F}\right] \mathrm{FDM}\end{array}$ & $\begin{array}{l}\text { TLC: Radiochemi- } \\
\text { cal purity }\left[{ }^{18} \mathrm{~F}\right] \\
\text { FDG }+\left[{ }^{18} \mathrm{~F}\right] \mathrm{FDM}\end{array}$ & $\begin{array}{l}\text { TLC: Radiochemi- } \\
\text { cal purity }\left[{ }^{18} \mathrm{~F}\right] \mathrm{FDG} \\
+\left[{ }^{18} \mathrm{~F}\right] \mathrm{FDM}\end{array}$ \\
\hline Tests & $\begin{array}{l}\text { MCA: Radio- } \\
\text { nuclide purity } \\
24 \mathrm{~h}+\end{array}$ & & & & $\begin{array}{l}\text { MCA: Radionuclide } \\
\text { purity } 24 \mathrm{~h}+\end{array}$ \\
\hline
\end{tabular}




\section{Highlights and recommendations from our studies}

- The shelf life depends on the starting amount of radioactivity, the radioactivity concentration, the content of stabilizers and the storage conditions.

- A thorough risk evaluation should be performed based upon the ICH guidelines including general considerations literature, general considerations experiences, stress testing, photostability, sampling, primary/secondary packaging, specification and evaluation and guidance/label for use.

- The stability evaluations and continuous evaluations or monitoring should have a defined plan

- Activity and the desired shelf-life must be defined by the production site.

- Ethanol is described as an important stabilizer in several studies and similarly investigated in different amounts with varying amounts of activity.

- With higher activities than $4 \mathrm{GBq} / \mathrm{mL}$ special care should be taken in monitoring the radiolysis and the side products that may occur.

- Ethanol content should be at least $0.1 \%$ up to $4 \mathrm{GBq} / \mathrm{mL}$ ( $>0.2 \%$ for activities up to $22.6 \mathrm{GBq} / \mathrm{mL}$ )

- Since GC Residual Solvents are exempt from a preliminary release of an $\left[{ }^{18} \mathrm{~F}\right] \mathrm{FDG}$ batch, it may agitate for leaving that test out of a stability study. However, because of the stabilizing effect of ethanol and the $0.1 \%$ recommendation GC analysis should be conducted throughout the studies, as ethanol will degrade to acetaldehyde and the stabilizing effect will be reduced accordingly.

- Recommended stability tests for the stability evaluations are according to Ph. Eur. and are listed in table 5 .

\section{Conclusions}

The formulation and production of $\left[{ }^{18} \mathrm{~F}\right] \mathrm{FDG}$ today, including choice of basic hydrolysis, $\mathrm{pH}$, time, and temperatures etc., are based on studies and discoveries that are partly summarized in this retrospective non-systematic literature study. The literature study thus confirms that the method used for the radiopharmaceutical production of $\left[{ }^{18} \mathrm{~F}\right] \mathrm{FDG}$ remains relevant today in light of new knowledge and technology. We have presented available stability data from several studies and even performed our own two independent stability studies which found the $\left[{ }^{18} \mathrm{~F}\right]$ FDG stable for 12 hours at room temperature up to $4 \mathrm{GBq} / \mathrm{mL}$ using ethanol as a radio-stabilizer.

\section{Abbreviations}

18F: [18F]Fluoride; BP: British pharmacopeia; CT: Computed tomography; CMC: Chemistry, manufacturing and controls; EMA: European Medicines Agency; EOB: End of bombardment; EOS: End of synthesis; FDA: Food and Drug Administration; FDG: Fluorodeoxyglucose; FDM: Fluorodeoxymannose; GC: Gas Chromatography; GMP: Good manufacturing practice; HPLC: High performance liquid chromatography; ICH: International Council for Harmonization of Technical Requirements for Registration of Pharmaceuticals for Human use's; MCA: Multi channel-analyzer; MR: Magnetic resonance; PET: Positron emission tomography; Ph. Eur.: European pharmacopeia; QC: Quality control; TLC: Thin layer chromatography; USP: United States pharmacopeia.

\section{Acknowledgements}

We gratefully acknowledge the support from the PET Imaging Centres at the University Hospital of North Norway, the University Hospital of Central Norway and UiT The Arctic University of Norway. The publication charges for this article have been funded by a grant from the publication fund of UiT The Arctic University of Norway. 


\section{Authors' contributions}

JGH and BR performed the stability studies. JGH performed the literature study with additions from RF. JGH, BR and RF analyzed and interpreted the data. RF wrote the manuscript with a major input from JGH. All authors read and approved the manuscript.

\section{Funding}

Open Access funding provided by UiT The Arctic University of Norway.

Availability of data and materials

The datasets used and/or analysed during the current study are available from the corresponding author on reasonable request.

\section{Declarations}

Ethics approval and consent to participate

Not applicable.

\section{Consent for publication}

Not applicable.

\section{Competing interests}

The authors declare that they have no competing interests.

\section{Author details}

'Department of Nuclear Medicine, The PET Imaging Centre, University Hospital of Central Norway, Ragnhilds gate 15, 7030 Trondheim, Norway. ${ }^{2}$ The PET Imaging Centre, University Hospital of North Norway, Hansine Hansens veg 82, 9019 Tromsø, Norway. ${ }^{3}$ Department of Health and Care Sciences, UiT The Arctic University of Norway, Hansine Hansens veg 18, 9019 Tromsø, Norway.

Received: 1 December 2021 Accepted: 3 February 2022

Published online: 24 February 2022

\section{References}

Buriova E, Macasek F, Kropacek M, Prochazka L. Autoradiolysis of 2-deoxy-2-[18F]fluoro-D-glucoseradiopharmaceutical. J Radioanal Nucl Chem. 2005:3:595-602.

Council of Europe, European pharmacopeia. 10th ed. Strasbourg: 2019

Dantas NM, Nascimento JE, Santos-Magalhães NS, Oliveira ML. Radiolysis of2-[18F]fluoro-2 deoxy-D-glucose ([18 F]FDG) and the role of ethanol, radioactive concentration and temperature of storage. Appl Radiat Isot. 2013;72:158-62.

European Medicines Agency. Guideline on radiopharmaceuticals, committee for human medicinal products. 2009. https://www.ema.europa.eu/en/documents/scientific-guideline/guideline-radiopharmaceuticals-revision-1_en.pdf. Accessed 1 May 2009

Fawdry RM. Radiolysis of 2-[18F]fluoro-2-deoxy-D-glucose (FDG) and the role of reductant stabilisers. Appl Radiat Isot. 2007;65:1193-201.

Ferreira SZ, Silva JBD, Waquil SS, Correia RF. Stability study of 2-[18f]fluoro-2-deoxy-d-glucose (18fdg) stored at room temperature by physicochemical and microbiological assays. In: International nuclear atlantic conference - inac 2009 rio de janeirorj, Brazil, Sseptember27 to October 2, 2009 associação brasileira de energia nuclear - aben isbn: 978-85-99141-03-8. 2009.

Füchtner F, Steinbach J, Mäding P, Johannsen B. Basic hydrolysis of 2-[18F]fluoro-1,3,4,6-tetra-O-acetyl-d-glucose in the preparation of 2-[18 F]fluoro-2-deoxy-D-glucose. Appl Radiat Isot. 1996;47:64-6.

Gallardo AR, Meneghetti G, Ragazzoni L, Kroumova V, Ferrante D, Ingrassia PL, Ruzza P, DellËra A, Boniolo E, Koraqe G, Faggiano F, Della-Corte F. Multiple withdrawals from single-use vials: a study on sterility. Int J Pharm. 2015;485:160-3.

Hamacher K, Coenen HH, Stöcklin G. Efficient stereospecific synthesis of no-carrier-added 2-[18 F]-fluoro-2-deoxy-Dglucose using aminopolyether supported nucleophilic substitution. J Nucl Med. 1986;2:235-8.

Hess S, Høilund-Carlsen PF, Alavi A. The first issue of clinical nuclear medicine and the first human FDG study. Clin Nucl Med. 1976;39(2014):701-3.

Hjelstuen OK, Svadberg A, Olberg DE, Rosser M. Standardization of fluorine-18 manufacturing processes: new scientific challenges for PET. Eur J Pharm Biopharm. 2011;78:307-13.

Huang Y, Taylor S, Koziorowski J, Chang Y, Kao W, Tzen K, Shiu C. A two-center study for the quality control pf $\left[{ }^{18} \mathrm{~F}\right] \mathrm{FDG}$ using FASTlab phosphate cassettes. Ann Nucl Med. 2016;30:563-71.

Hung JC. Comparison of various requirements of the quality assurance procedures for 18F-FDG injection. J Nucl Med. 2002:43:1495-506.

International Council of Harmonisation of Technical Requirements for Pharmaceuticals for Human Use (ICH), evaluation for stability data Q1E. 2003b. https://www.ich.org/page/quality-guidelines. Accessed 1 Aug 2003.

International Council of Harmonisation of Technical Requirements for Pharmaceuticals for Human Use (ICH), stability testing of new drug substances and products Q1A (R2). 2003a. https://www.ich.org/page/quality-guidelines. Accessed 1 Aug 2003

Jacobson MS, Dankwart HR, Mahoney DW. Radiolysis of 2-[18 F]fluoro-2-deoxy-D-glucose( $\left.\left({ }^{18} \mathrm{~F}\right] \mathrm{FDG}\right)$ and the role of ethanol and radioactive concentration. Appl Radiat Isot. 2009;67:990-5. 
Jiménez Romero IR, Roca Engronyat M, Campos Añón F, Cordero Ramajo J, Liarte Trías I, Benítez Segura A, Bajén Lázaro M, Ferrán Sureda N, Puchal Añé R, Gámez Cenzano C. Influence of radioactive concentration and storage time on radiochemical purity of ${ }^{18} \mathrm{~F}-\mathrm{FDG}$. Rev Esp Med Nucl. 2006;45:20-5.

Jószai I, Svidró M, Pótári N. Recommendations for selection of additives for stabilization of 18F]FDG. Appl Radiat Isot. 2019:146:78-83.

Khalil MM, editor. Basic science of PET imaging. Cham: Springer; 2017.

Kiselev MY, Tadino V. Stabilization of radiopharmaceuticals labeled with 18-F, lon beam applications U.S. Patent US7018614B2. 2006

Long JZ, Jacobson MS, Hung JC. Comparison of FASTlab 18F-FDG production using phosphate and citrate buffer cassettes. J Nucl Med Technol. 2013;41:32-4.

Meyer GJ, Matzke KH, Hamacher K, Füchtner F, Steinbach J, Notohamiprodjo G, Ziilstrad S. The stability of 2-[18 F]fluorodeoxy-d-glucose towards epimerisation under alkaline conditions. Appl Radiat Isot. 1999;51:37-41.

Mosdzianowski C, Lemaire C, Simoens F, Aerts J, Morelle J-L, Luxen A. Epimerization study on $\left[{ }^{18}\right.$ F]FDG produced by an alkaline hydrolysis on solid support under stringent conditions. Appl Radiat Isot. 2002;56:871-5.

Rahmani S, Shahhoseinia S, Mohamadia R, Vojdania M. Synthesis, quality control and stability studies of 2-[ $\left.{ }^{18} \mathrm{~F}\right]$ fluoro2-deoxy-D-glucose $\left({ }^{18} \mathrm{~F}\right.$-FDG) at different conditions of temperature by physicochemical and microbiological assays, Iran. J Pharm Res. 2017;16:602-10.

Rensch C, Waengler B, Yaroshenko A, Samper V, Baller M, Heumesser N, Ulin J, Riese S, Reischl G. Microfluidic reactor geometries for radiolysis reduction in radiopharmaceuticals. Appl Radiat Isot. 2012;70:1691-7.

U.S. Food and Drug Administration. PET drugs_current good manufacturing practice (CGMP), (Small Entity Compliance Guide). B. Guidance on Stability. August 2011. p. 27.

U.S. Food and Drug Administration. 21 CFR Part 212 current good manufacturing practice for positron emission tomography drugs. 2015. http://www.accessdata.fda.gov/scripts/cdrh/cfdocs/cfCFR/CFRSearch.cfm?CFRPart=212. Accessed 1 Nov 2019

Walters LR, Martin KJ, Jacobson MS, Hung JC, Mosman EA. Stability evaluation of 18F-FDG at high radioactive concentrations. J Nucl Med. 2011;52(supplement 1):2413.

Yu S. Review of 18F-FDG synthesis and quality control. Biomed Imaging Interv J. 2006;4:1-11.

\section{Publisher's Note}

Springer Nature remains neutral with regard to jurisdictional claims in published maps and institutional affiliations.

\section{Submit your manuscript to a SpringerOpen ${ }^{\circ}$ journal and benefit from:}

- Convenient online submission

- Rigorous peer review

- Open access: articles freely available online

- High visibility within the field

- Retaining the copyright to your article

Submit your next manuscript at $\boldsymbol{\nabla}$ springeropen.com 